\author{
Rafał GAŁEK ${ }^{1}$ \\ Pawel GIL ${ }^{2}$ \\ Sebastian GROSICKI ${ }^{3}$ \\ Franciszek WOLAŃCZYK ${ }^{4}$
}

\title{
WYMIENNIKOWY ZASOBNIK CIEPŁA W MIKROKOGENERACJI
}

\begin{abstract}
Artykuł przedstawia wyniki eksperymentalne okresowego badania efektów pracy wolno stojącego wymiennika $\mathrm{z}$ wężownicą spiralną jako zasobnika ciepła w instalacji kogeneracji opartej na małej jednostce kogeneracyjnej GECC60A2N firmy AISIN. Zasobnik jako bufor ciepła ma zapewnić możliwość dostarczenia czynnika grzewczego do odbiorcy przy chwilowym poborze większym niż wydajność źródła ciepła. Czasowy okres badań instalacji mikrokogeneracji wyznaczało rozpoczęcie ładowania zasobnika, a zakończenie badań to włączenie zewnętrzne chłodzenia kogeneratora. Otrzymane wartości pomiarów mocy cieplnej kogeneratora zasilającego zasobnik w ciepło mają tendencję spadkową, dochodzącą do $60 \%$ początkowej mocy.
\end{abstract}

Słowa kluczowe: kogeneracja, mikro CHP, zasobnik ciepła

\section{Wprowadzenie}

Kogeneracja jest jednoczesnym wytwarzaniem energii elektrycznej i ciepła, przy czym energia cieplna jest odzyskiwana do celów grzewczych lub technologicznych. Jednoczesne wytwarzanie ciepła i energii elektrycznej zapewnia lepsze wykorzystanie paliwa pierwotnego, zmniejszając negatywne oddziaływanie na środowisko. Wpływa również korzystnie na wynik ekonomiczny inwestycji. Mikrokogeneracyjny system (mikro CHP) wytwarza ciepło i energię elektryczną, głównie za pomocą tłokowego silnika spalinowego, od którego ciepło grzejne jest pobierane z systemu chłodzenia silnika i z gazów wylotowych odpływających z silnika, do wykorzystania na potrzeby grzewcze, głównie w budynkach mieszkalnych. Mikro CHP może pracować ze stałą mocą elektryczną, nie wy-

\footnotetext{
${ }^{1}$ Autor do korespondencji/corresponding author: Rafał Gałek, Politechnika Rzeszowska, al. Powstańców Warszawy 8, 35-959 Rzeszów, tel.: (17) 86251341, e-mail: rafalgalek@prz.edu.pl

2 Paweł Gil, Politechnika Rzeszowska, e-mail: gilpawel@prz.edu.pl

${ }^{3}$ Sebastian Grosicki, Politechnika Rzeszowska, e-mail: sebogr@prz.edu.pl

${ }^{4}$ Franciszek Wolańczyk, Politechnika Rzeszowska, e-mail: fwolan@prz.edu.pl
} 
stępuje też wpływ odprowadzania ciepła grzejnego na wytwarzaną moc elektryczną. Powoduje to, że sprawność energetyczną całego układu można obliczać tylko z uwzględnieniem obydwu efektów energetycznych [3].

Ideą zbiorników akumulacyjnych jest magazynowanie nadwyżek energii cieplnej związanych z okresowym, zmiennym zapotrzebowaniem na ciepło. Energia, która powstała w procesie spalania paliwa w kogeneratorze, jest akumulowana przez czynnik grzewczy (zazwyczaj wodę), zapewniający jej późniejsze wykorzystanie. W wymiennikowym zasobniku ciepła woda jest ogrzewana przez czynnik grzewczy przepływający wężownicą spiralną umiejscowioną w zbiorniku akumulacyjnym, stopniowo ładując ciepłem zbiornik przez przenikanie ciepła. Zaletą akumulacji, w porównaniu z układem niezawierającym zbiornika akumulacyjnego, jest racjonalne wykorzystanie energii paliwa i w związku z tym oszczędność paliwa, jak i możliwość zmniejszenia projektowanej mocy cieplnej planowanego źródła w stosunku do zapotrzebowania (lub zwiększenia o tyle samo mocy cieplnej źródła istniejącego).

Niniejszy artykuł jest próbą odpowiedzi na pytanie o spodziewane efekty współpracy mikrokogeneratora $\mathrm{z}$ zasobnikiem ciepła podczas braku odbioru ciepła od zasobnika na zewnątrz układu.

\section{Charakterystyka układu}

W Laboratorium Energii Słonecznej i Energii Cieplnej Otoczenia Katedry Termodynamiki i Mechaniki Płynów Wydziału Budowy Maszyn i Lotnictwa Politechniki Rzeszowskiej kogenerator jest częścią większego układu, obejmującego fototermiczne kolektory solarne, średniookresowy akumulator ciepła oraz dwie pompy ciepła: sprężarkową i absorpcyjną. Funkcjonowanie poszczególnych urządzeń jest powiązane uwarunkowaniami wynikającymi ze struktury układu odbioru ciepła, dlatego pracują one pod kontrolą nadrzędnego układu sterowania automatycznego, spełniającego również zadania akwizycji i prezentacji danych pomiarowych. Zastosowaną w układzie jednostką jest mikrokogenerator GECC60A2N firmy AISIN (rys. 1.) o mocy elektrycznej $6 \mathrm{~kW}$ i mocy cieplnej $11,7 \mathrm{~kW}$. Jest on wyposażony $\mathrm{w}$ trzycylindrowy silnik $\mathrm{z}$ rozrządem OHV o pojemności $952 \mathrm{~cm}^{3}$, spalający gaz ziemny w postaci ubogiej mieszanki $\mathrm{z}$ powietrzem (ang. lean-burn). Pozostałe dane techniczne od producenta podano w tab. 1.

Silnik napędza trójfazowy generator synchroniczny, z którego prąd jest prostowany, a następnie kierowany do falownika dostosowującego parametry wytworzonej energii elektrycznej do wymagań sieci i zapewniającego synchronizację umożliwiającą włączenie kogeneratora $\mathrm{w}$ instalację elektryczną budynku. Kogenerator jest posadowiony na tarasie budynku laboratorium i spaliny są odprowadzane bezpośrednio do otoczenia. Na wyjściu z kogeneratora wartość napięcia posiada parametry stosowane $\mathrm{w}$ japońskim standardzie sieci niskiego napięcia, czyli 100/200 V, dostarczane przy użyciu 3 przewodów. Dyktuje to 
konieczność zastosowania dodatkowego zewnętrznego transformatora. Zintegrowany układ sterowania pozwala jednostce na pracę z ułamkiem mocy nominalnej kierowaną do odbiorników w obwodzie wydzielonym, natomiast chłodnica wentylatorowa uniezależnia wytwarzanie energii elektrycznej od aktualnego zapotrzebowania na ciepło.

Rys. 1. Kogenerator GECC60A2N firmy AISIN

Fig. 1. AISIN GECC60A2N cogeneration system

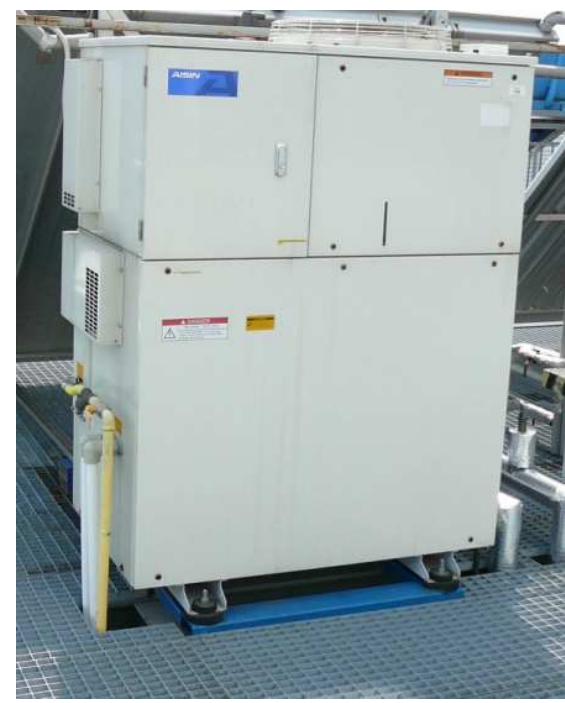

Tabela 1. Fabryczne dane techniczne kogeneratora GECC60A2N (na podstawie [1])

Table 1. Technical specification of the GECC60A2N cogeneration system (on the basis of [1])

\begin{tabular}{|l|l|}
\hline Firma & AISIN \\
\hline Model & GECC60A2N \\
\hline Moc elektryczna & $6 \mathrm{~kW}$ \\
\hline Moc cieplna & $11,7 \mathrm{~kW}$ \\
\hline Temperatura nośnika ciepła & $60-65^{\circ} \mathrm{C}$ \\
\hline Strumień energii chemicznej paliwa & $20,8 \mathrm{~kW}$ \\
\hline Rodzaj paliwa & gaz ziemny \\
\hline Silnik spalinowy & $\begin{array}{l}\text { pionowy, 4-suwowy, 3-cylindrowy, mieszanka uboga } \\
\text { (ang. lean-burn) }\end{array}$ \\
\hline Pojemność silnika spalinowego & $952 \mathrm{~cm}^{3}$ \\
\hline $\begin{array}{l}\text { Znamionowa prędkość obrotowa } \\
\text { silnika spalinowego }\end{array}$ & $1600-1800$ obr./min \\
\hline Prądnica & synchroniczna, 16-polowa, na magnesach trwałych \\
\hline Sprawność elektryczna & $28,8 \%$ \\
\hline Sprawność cieplna & $56,2 \%\left(60-65^{\circ} \mathrm{C}\right)$ \\
\hline EUF & $85 \%$ \\
\hline
\end{tabular}


Ciepło jest odbierane w wymienniku spaliny-chłodziwo oraz płaszczu silnika, a następnie w kolejnym wymienniku oddawane do czynnika roboczego, który stanowi płyn termalny na bazie $40 \%$ roztworu glikolu propylenowego. Glikol jest kierowany do rur w kształcie wężownic spiralnych umieszczonych wewnątrz zasobnika ciepła, oddając ciepło na sposób przenikania przez ścianki rur do wody zasobnika.

Przyłącze elektryczne do instalacji budynku jest zrealizowane za pomocą transformatora oraz skrzynki przyłączeniowej zawierającej elementy zabezpieczające i sygnalizacyjne. Ponadto zastosowano dwa liczniki energii elektrycznej, z których jeden mierzy energię zwracaną przez kogenerator do sieci, natomiast drugi energię pobieraną do napędu pomp obiegowych roztworu glikolu.

Sterowanie pracą kogeneratora odbywa się z uwzględnieniem zapotrzebowania na ciepło. Ponieważ nie jest możliwa regulacja mocy cieplnej jednostki, ma ono charakter dwustanowy. Decyzja o włączeniu kogeneratora zostaje podjęta na podstawie wartości temperatur w zasobniku CWU (T5) (rys. 2.), zasobniku wody kotłowej oraz linii powrotu instalacji CO budynku. Dzięki zaworowi trójdrogowemu $(Z)$ jest realizowany priorytet CWU. Włączony kogenerator pracuje cały czas z nominalną mocą elektryczną równą $6 \mathrm{~kW}$, a cała wytworzona energia elektryczna jest zużywana na potrzeby budynku.

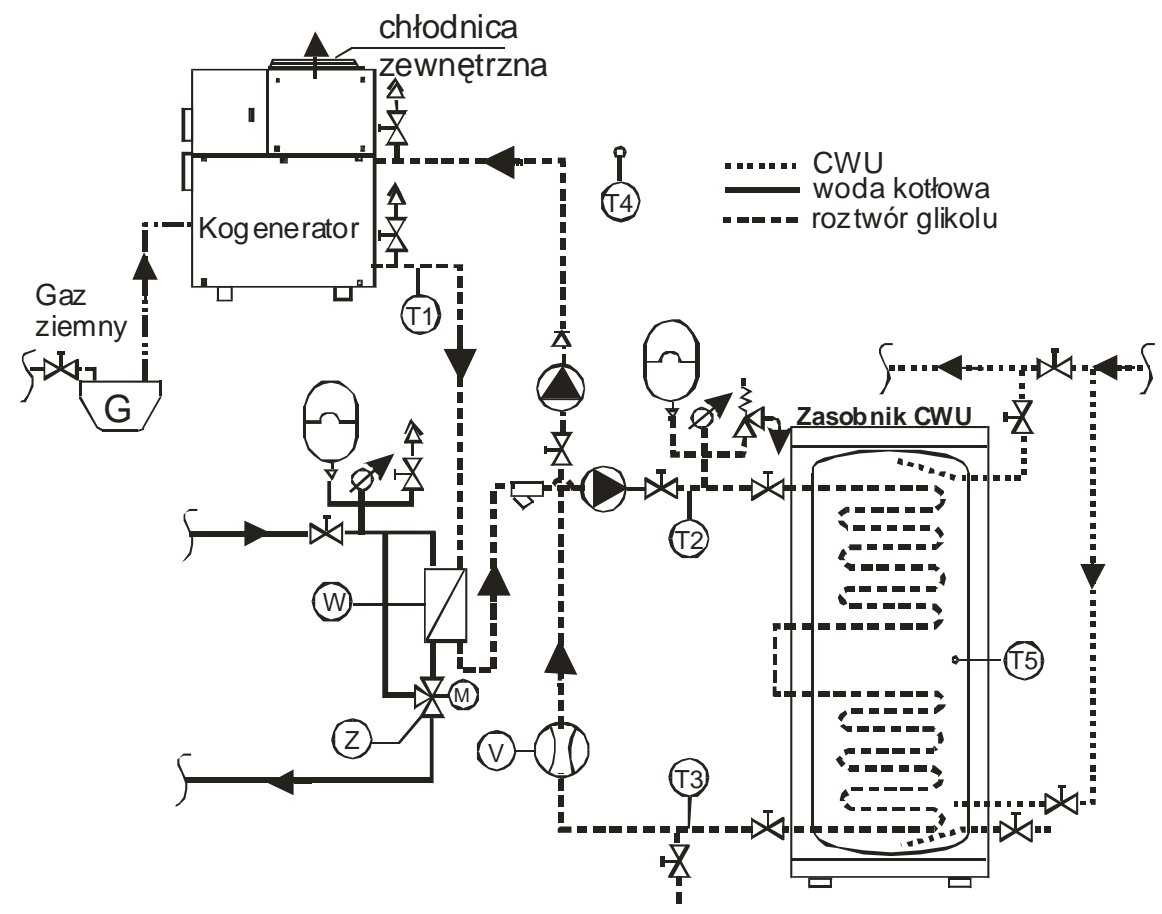

Rys. 2. Schemat instalacji mikrokogeneratora

Fig. 2. Schema of microcogeneration installation 
Rys. 3. Podgrzewacz UNO/2 500 firmy De Dietrich

Fig. 3. Hot water tank UNO/2 500 of the De Dietrich company

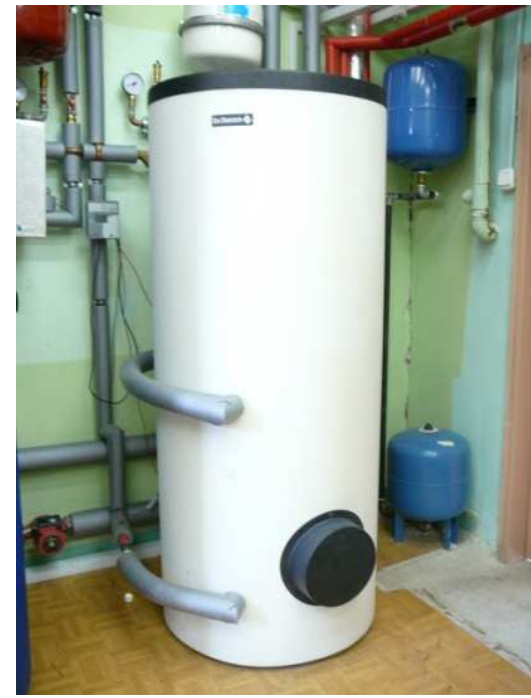

Włączanie i wyłączanie kogeneratora oraz obrotów głowicy zaworu trójdrogowego (Z) odbywa się za pośrednictwem przekaźników karty wyjść dwustanowych jednostki Keithley 3706 pełniącej w układzie rolę zarówno multimetru, jak i sterownika. W skali całej instalacji Laboratorium sterownik obsługuje kilkadziesiąt wejść (głównie termometry oporowe) oraz kilkanaście wyjść sterujących pracą pomp i zaworów. Przez magistralę USB jest podłączony do komputera, na którym pracuje program odpowiedzialny za podejmowanie decyzji sterujących na podstawie danych wejściowych oraz akwizycję i prezentację wyników pomiarów. Część danych charakteryzujących pracę układu CHP jest uzyskiwana dzięki podłączeniu jej wewnętrznego sterownika do portu szeregowego RS232 komputera. Ponieważ wśród tych parametrów nie ma informacji o wydatku roztworu glikolu, zastosowano dodatkowo licznik ciepła (V) Kamstrup MULTICAL 402 włączony tak, aby mierzyć ciepło oddane do zasobnika CWU (czujniki temperatury T2 i T3 na rys. 2.). Istotną zaletą licznika jest możliwość odrębnego odczytu wartości wielkości mierzonych bezpośrednio: wydatku objętościowego czynnika oraz temperatur zasilania i powrotu.

Zasobnik ciepła stanowi podgrzewacz solarny typu UNO/2 500 firmy De Dietrich (rys. 3.), będący stalowym zbiornikiem o pojemności 500 litrów. Zbiornik jest pokryty od wewnątrz emalią w celu ochrony zasobnika przed korozja i zachowania jakości wody. Na zewnątrz zasobnik jest izolowany bezfreonowa pianką poliuretanową o grubości $50 \mathrm{~mm}$.

Wewnątrz zbiornika są dwa wymienniki ciepła: jeden w górnej części, o pojemności 10,9 litra i powierzchni grzewczej $1,5 \mathrm{~m}^{2}$, drugi zaś w dolnej części zbiornika, o pojemności 4,9 litra i powierzchni grzewczej $0,72 \mathrm{~m}^{2}$ [2]. Wymienniki wykonano z gładkiej rury z powierzchnią od strony wody użytkowej pokrytą emalią. Są ukształtowane spiralnie oraz połączone ze sobą w szereg. 


\section{Wyniki pomiarów}

Czasowy okres badań instalacji mikrokogeneracji (170 min) wyznaczało uruchomienie kogeneratora i rozpoczęcie ładowania zasobnika, a zakończenie badań to włączenie zewnętrzne chłodzenia kogeneratora. Ciepło od zasobnika nie było odbierane (na zewnątrz), temperatura wody w zasobniku rosła od początkowej $23^{\circ} \mathrm{C}$ do końcowej $65^{\circ} \mathrm{C}$ (rys. 4 .).

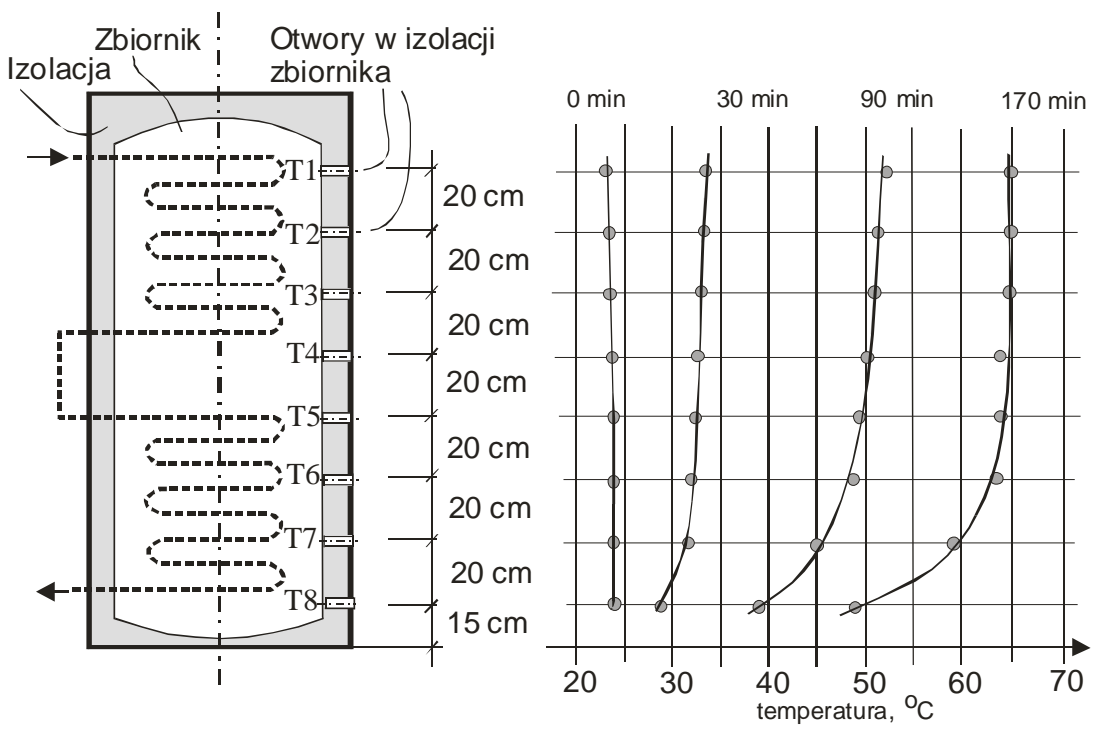

Rys. 4. Rozkład temperatury w zasobniku ciepła w funkcji czasu

Fig. 4. The temperature distribution in the heat storage tank as a function of time

Na rysunku 4. pokazano osiem miejsc pomiaru temperatury wody termoparą (co $10 \mathrm{~min}$ ). Przeprowadza się pomiar zewnętrznej powierzchni zbiornika przez wykonane w izolacji otwory. Pokazano początkowy i końcowy rozkład temperatury oraz dwa stany pośrednie dla czasu 30 i $90 \mathrm{~min}$. Tak przeprowadzony pomiar temperatury odzwierciedla raczej układ temperatury warstw wody w funkcji wysokości stojącego zasobnika. Widoczne jest niedogrzanie dolnej części, gdy wymiennik dolny ma mniejszą powierzchnię wymiany ciepła w porównaniu z wymiennikiem w części górnej.

Moc cieplną kogeneratora określono za pomocą wzoru

$$
\dot{Q}=\dot{m} \cdot c \cdot\left(T_{2}-T_{3}\right)
$$

gdzie: $\dot{m}$ - strumień glikolu $[\mathrm{kg} / \mathrm{s}], c$ - ciepło właściwe glikolu [kJ/(kg.K)], $T_{2}$, $T_{3}$ - temperatura glikolu w miejscu zasilania i powrotu z zasobnika ciepła $\left[{ }^{\circ} \mathrm{C}\right]$. 
Zmianę mocy cieplnej kogeneratora w czasie pomiaru pokazano na rys. 5. Pomiary mocy wykonywano co minutę, od momentu włączenia kogeneratora, stąd zerowe wskazania początkowe, gdyż kogenerator uruchamia się w 6. min i od tego czasu wzrasta moc cieplna, osiagając maksimum po 60 . min pracy. Średnia sprawność całkowita $(E U F)$ kogeneratora w okresie pomiarów (170 min), według pracy [3], została określona ze wzoru:

$$
E U F=\frac{E_{e l}+Q}{P W_{d}}
$$

gdzie: $E_{e l}$ - ilość energii elektrycznej wyprodukowanej w okresie pomiarów, $Q$ - ilość ciepła wyprodukowanego w okresie pomiarów, jako $Q=\sum_{i} \dot{Q}_{i} \cdot t_{i}, \dot{Q}_{i}-$ średnia wartość mocy cieplnej kolejnych pomiarów dla czasu $t_{i}=10 \min , P$ - ilość spalonego paliwa gazowego, $W_{d}$ - wartość opałowa gazu ziemnego; $W_{d}=31 \mathrm{MJ} / \mathrm{m}^{3}$.

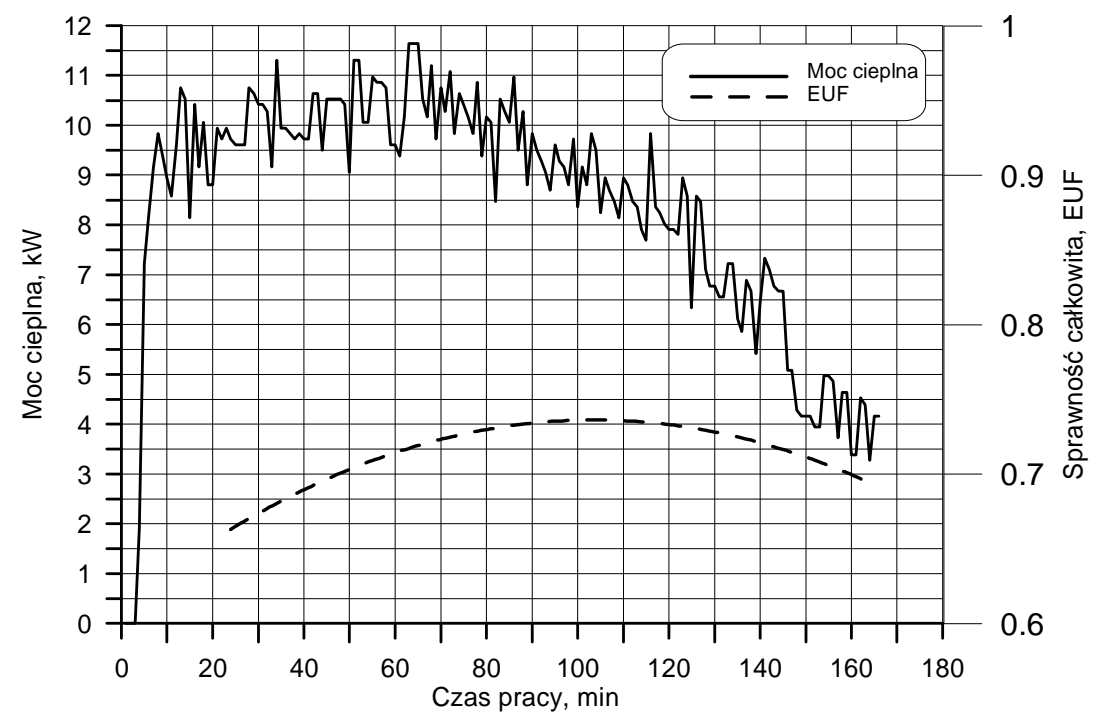

Rys. 5. Zmiana mocy cieplnej i sprawności całkowitej kogeneratora

Fig. 5. Changing the thermal power and total efficiency of the cogenerator

Obliczoną zmianę sprawności całkowitej kogeneratora aproksymowano wielomianem $E U F=0,6124+0,0024 t-1,154 \cdot 10^{-5} t^{2}$, co ukazuje linia przerywana na rys. 5. Zmiana sprawności jest spowodowana zmniejszającą się mocą cieplną kogeneratora, gdyż moc elektryczna kogeneratora przekazywana do sieci energetycznej pozostaje stała. 


\title{
4. Podsumowanie
}

Wykonano pomiary mocy cieplnej i sprawności całkowitej kogeneratora podczas ładowania zasobnika, od którego nie odbierano ciepła na zewnątrz. Obliczona z pomiarów maksymalna całkowita sprawność kogeneratora jest około $12 \%$ niższa niż maksymalna sprawność całkowita deklarowana przez producenta. Otrzymane wartości pomiarów mocy cieplnej kogeneratora zasilającego zasobnik w ciepło, od którego nie odbierano ciepła na zewnątrz, mają tendencję spadkową, dochodzącą do $60 \%$ początkowej mocy, co jest spowodowane wzrostem temperatury wody w zasobniku.

\section{Podziękowania}

Prace były prowadzone na aparaturze naukowo-badawczej zakupionej w projekcie nr POPW.01.03.00-18-012 z funduszy strukturalnych w ramach Programu Operacyjnego Rozwój Polski Wschodniej współfinansowanego przez Unię Europejską ze środków Europejskiego Funduszu Rozwoju Regionalnego.

\section{Literatura}

[1] Gas Engine Cogeneration System Interconnection with Power Grid System Type. Installation Manual, GECC60A2 N AISIN Toyota group 2006.

[2] Instrukcja Inisol-UNO-1-2_IIN-IT-IO.pdf, www.dedietrich.pl.

[3] Skorek J., Kalina J.: Gazowe układy kogeneracyjne. Wydawnictwa Naukowo-Techniczne, Warszawa 2005.

\section{STORAGE TANK WITH HEAT EXCHANGER AT MICROCOGENERATION SYSTEMS}

\begin{abstract}
S u m m a r y
This article presents the results of experimental periodic studies on the effect of work of a free-standing exchanger with a spiral coil as a heat storage tank in the cogeneration installation based on the small AISIN GECC60A2N cogeneration unit. The heat storage tank as a heat buffer is to deliver the heating medium during the temporary request greater than the heat source efficiency. Investigations of cogeneration were started at the moment of heat storage tank and it was finished at startup of external cooling of the cogenerator. The measurement values of thermal power of cogenerator feeding the heat accumulator tend to decrease to $60 \%$ of the initial power.
\end{abstract}

Keywords: cogeneration, micro CHP, heat storage tank

DOI: $10.7862 / \mathrm{rm} .2014 .52$

Otrzymano/received: 2.09.2014 r.

Zaakceptowano/accepted: 22.11.2014 r. 